\title{
Non-specific activation of antiviral immunity and induction of RNA interference may engage the same pathway in the Pacific white leg shrimp Litopenaeus vanname $i^{\text {in }}$
}

\author{
Yannick Labreuche ${ }^{\mathrm{a},{ }^{*}}$, Artur Veloso $^{\mathrm{a}}$, Enrique de la Vega ${ }^{\mathrm{a}, 1}$, Paul S. Gross $^{\mathrm{b}, 2}$, Robert W. Chapman $^{\mathrm{c}}$, \\ Craig L. Browdy ${ }^{\mathrm{c}, 3}$ and Gregory W. Warr ${ }^{\mathrm{a}, \mathrm{b}, 4}$
}

\footnotetext{
${ }^{a}$ Marine Biomedicine and Environmental Sciences Center, Medical University of South Carolina, 221 Ft. Johnson Road, Charleston, SC 29412, USA

${ }^{\mathrm{b}}$ Department of Biochemistry and Molecular Biology, Medical University of South Carolina, Charleston, SC 29425, USA

c Marine Resources Institute, South Carolina Department of Natural Resources, 217 Ft. Johnson Road, Charleston, SC 29412, USA

${ }^{1}$ Present address: CI OCEANOS S.A. Carretera a Mamonal No. 1 - 504, Cartagena, Colombia.

2 Deceased.

${ }^{3}$ Present address: Novus International, 5 Tomotley Ct., Charleston, SC 29407, USA.

${ }^{4}$ Present address: Division of Molecular and Cellular Biosciences, National Science Foundation, Arlington, VA 22230, USA.

स This material is based in part on work supported by the National Science Foundation. Any opinion, finding, and conclusions or recommendations expressed in this material are those of the author and do not necessarily reflect the views of the National Science Foundation.
}

\footnotetext{
*: Corresponding author : Yannick Labreuche, Tel.: +687 3525 88; fax: +687 3511 77, email address : yannick.labreuche@ifremer.fr
}

\begin{abstract}
:
Many questions remain unanswered regarding RNAi-based mechanisms and dsRNA-induced antiviral immune responses in penaeid shrimp. In this study, we report the characterization in the white leg shrimp Litopenaeus vannamei of RNAi pathway associated proteins Lv-Ago 1 and Lv-Ago 2, two members of the Argonaute family of proteins, as well as LV-sid 1, the first shrimp homologue of Sid-1, a membrane channel-forming protein implicated in the cellular import of dsRNA. To decipher their functional implication in RNAi-related phenomena, we monitored their relative expression following stimulation by specific and non-specific RNA duplexes of diverse length. The findings show that the length of small RNA duplexes plays a critical role in the activation of both RNAi-related and innate antiviral responses. They also suggest that these two mechanisms of antiviral response may activate the same pathway, requiring Lv-Sid 1 and Lv-Ago 2 induction.
\end{abstract}

Keywords: Shrimp; Litopenaeus vannamei; RNAi; dsRNA; Argonaute; Sid-1; Antiviral immunity 


\section{Introduction}

RNA interference (RNAi) is a nucleic acid-based mechanism widely conserved among all higher eukaryotes studied so far, that mediates sequence-specific targeted gene silencing. This process is initiated by double-stranded RNA (dsRNA), which is processed by a member of the Dicer family of RNase-III-like enzymes into small effector RNA duplexes (e.g. short-interfering RNAs or siRNAs, microRNAs or miRNAs, etc). The siRNAs are incorporated into a multimeric protein complex, the RNA-induced silencing complex (RISC) and related complexes, of which an Argonaute (Ago) family protein forms the catalytic core. The incorporated RNA then directs the targeted sequence-specific degradation, translational repression, and other silencing phenomena by means of complementary base-pairing. The RNAi mechanism is involved in a variety of biological phenomena including developmental processes (Grishok et al., 2001), heterochromatin remodelling (Riddle and Elgin, 2008), suppression of transposon activity (Aravin et al., 2007) and antiviral immunity (Li and Ding, 2005). Because dsRNA or siRNAs can be supplied exogenously to trigger specific gene silencing, RNAi has rapidly become the most widely used gene-silencing tool in a broad variety of eukaryotic organisms (Campbell and Choy, 2005).

In penaeid shrimp, exploiting this process is becoming increasingly important as an experimental tool to unravel gene function in vivo. This is exemplified by the increasing number of studies which have recently resolved gene functions involved in molting (Hui et al., 2008), osmo-regulation (Tiu et al., 2007), reproduction (Treerattrakool et al., 2008), glucose metabolism (Lugo et al., 2006) or immune responses (de la Vega et al., 2008; Shockey et al., 2009) in shrimp by using gene-specific dsRNA technology. RNAi-based applications have also offered new opportunities for experimental blockade of viral infections in shrimp by injecting animals with virus-specific RNA duplexes (as first described by (Robalino et al., 2005), providing thus a potential approach for virus control in the shrimp farming industry (Shekhar and Lu, 2009). An additional promising avenue of this technology is the observed partial protection from viral infection induced by dsRNA of diverse length, sequence, and base composition (Robalino et al., 2004). Development of methods for induction of this dsRNA-induced innate immunity could be of great interest for aquaculture.

The existence of an intact RNAi machinery in shrimp was first supported by the identification of RNAi pathway homologues such as Pem-AGO in the black tiger shrimp $P$. monodon (Dechklar et al., 2008) and Pm-Ago, another isoform of the Argonaute protein family (Unajak et al., 2006), as well as Pm Dcr1, a member of the Dicer family (Su et al., 2008). However, although a substantially impaired RNAi was observed in Pem-agodepleted cells, suggesting its functional involvement in the silencing process (Dechklar et al., 2008), many questions remain unanswered regarding RNAi-based mechanism in penaeids. First, the core of this machinery and its regulation remain poorly understood. Second, it is still not known whether cross-talk and/or interactions occur between RNAi and the sequence-independent antiviral immunity observed following dsRNA injections. Finally, important efficiency discrepancies to promote gene-silencing have been reported following siRNA injections ( Li et al., 2007; Robalino et al., 2005; Westenberg et al., 2005; Wu et al., 2007; Wu et al. 2008). These inconsistencies need to be explored to improve efficacy in RNAi-based applications in shrimp aquaculture.

This study was therefore aimed at characterizing RNAi-pathway associated components in the white leg shrimp L. vannamei. Specifically, the present work was designed i) to decipher the functional implication of these components in both innate and RNAi-related phenomena by monitoring their relative expression following stimulation by small RNA 
duplexes and ii) to determine the effect of dsRNA length on targeted genetic interference and general antiviral protection.

\section{Materials and methods}

\subsection{Animals and RNA extractions}

L. vannamei shrimp from specific pathogen-free (SPF) lines were used for all experiments. Gills were collected in RNA later reagent (Ambion) and stored at $-20^{\circ} \mathrm{C}$ until use. Total RNA was extracted using RNeasy columns (Qiagen) according to the manufacturer's instructions. RNA quantity, purity and integrity were verified spectrophotometrically $\left(A_{260} / A_{280}\right)$ and by electrophoresis on $1 \%$ agarose gels.

\subsection{Cloning of $L v$-ago $1, L v$-ago 2 and $L v$-sid 1 full-length cDNAs}

To isolate a cDNA of $L v$-ago 1, specific primers (G-3524 and G-3525, Table 1) were designed on a consensus sequence of Argonaute proteins and used for PCR amplification from gill cDNA. PCR was performed as follows: initial denaturation at $95^{\circ} \mathrm{C}$ for 5 min; followed by 30 cycles at $95^{\circ} \mathrm{C}$ for $30 \mathrm{~s} ; 52^{\circ} \mathrm{C}$ for $1 \mathrm{~min} ; 72^{\circ} \mathrm{C}$ for $1 \mathrm{~min}$. The full-length CDNA of $L V$-ago 1 was obtained by performing 5'- and 3'-RACE-PCR with the SMART ${ }^{\text {TM }}$ RACE CDNA Amplification kit (Clontech/BD Biosciences) using the supplied universal primer mix in combination with either 5'RACE-primer G-3597 or 3'RACE-primer G-3595 (Table 1). Amplification profiles for RACE-PCR consisted of 30 cycles of $94^{\circ} \mathrm{C}$ for $30 \mathrm{~s}$, $68^{\circ} \mathrm{C}$ for $30 \mathrm{~s}$ and $72^{\circ} \mathrm{C}$ for $3 \mathrm{~min}$.

Based on L. vannamei expressed sequence tag (EST) sequences homologous to Argonaute and Sid-1 proteins, available at www.marinegenomics.org (O'Leary et al., 2006), 5'RACE-primer G-3816 and 5'RACE-primer G-3780 were designed to obtain the 5'end CDNA sequences of LV-Sid 1 and LV-Ago 2 proteins by RACE-PCR, as described above. Finally, the full-length cDNAs of $L v$-ago $1, L v$-ago 2 and $L v$-sid-1 were amplified by PCR using specific primers (G-3608/G-3609, G-3822/G-3823 and G-3853/G-3854, respectively) designed at $5^{\prime}$ and $3^{\prime}$ extremities (Table 1 ) with the BD Advantage 2 polymerase mix (Clontech).

\subsection{Phylogenetic tree constructions}

A list of known sequences of the members of Argonaute and Sid-1 proteins was obtained from GenBank and EMBL databases using the BLAST (Basic Local Alignment Search Tool) program (Altschul et al., 1997). Trees were built using the MEGA 4 software (Molecular Evolutionary Genetics Analysis, version 4.0) applied to the Neighbor-Joining method (Tamura et al., 2007). Multiple alignments of amino acid sequences were created using the Piwi and multiple transmembrane conserved domains for Argonaute and Sid-1like proteins, respectively. Bootstrap values (\%) of 10000 replicates were calculated for each node of the consensus tree obtained. 


\subsection{Preparation of dsRNA}

Double-stranded RNAs (dsRNA) were generated as previously described (Robalino et al., 2004). The DNA templates used for in vitro transcription were pCR4 vectors (Invitrogen) hosting different size fragments (50, 100, 150 and $200 \mathrm{bp}$ ) amplified either from the fulllength CDP (CUB domain protein) cDNA (GenBank acc. no. AY907539) or from a 309-bp portion of the immunoglobulin $U$ (Igu) cDNA from the duck, Anas platyrhynchos (AJ312200), using specific primers indicated in Table 1. Synthetic siRNAs with UU 3' overhangs specific for duck Igv (Igv siRNA, GGGTTGCCCATGAGGTTCA) and for CDP (CDP SIRNA 1, ACTCACCTGGCTGATGTTC; CACAACCAAGGAACTGATC; CDP SiRNA 3, ATTCCACAGCAACAGTGCT) were purchased from Ambion. Finally, siRNA and dsRNAs were diluted to a final concentration of $250 \mathrm{ng} / \mu \mathrm{l}$ in sterile saline solution $(10 \mathrm{mM}$ Tris- $\mathrm{HCl} \mathrm{pH} \mathrm{7.5,400} \mathrm{mM} \mathrm{NaCl})$ and stored at $-80^{\circ} \mathrm{C}$.

\subsection{Preparation of viral inoculum and experimental infection}

The bioassay system, experimental animals, and white spot syndrome virus (WSSV) inoculum used here have been previously described (Prior et al., 2003; Robalino et al., 2004). Briefly, $1.0-1.5 \mathrm{~g}$ SPF $L$. vannamei shrimp (30 shrimp/treatment) were intramuscularly injected with $5 \mu \mathrm{g}(20 \mu \mathrm{l}$ volume) of either siRNA, dsRNA or sterile saline, and $48 \mathrm{~h}$ later injected again with either saline (negative controls) or a WSSV inoculum used at a $5 \times 10^{-8}$ dilution (weight of infected tissue:volume of saline), to typically yield mortalities close to $80 \%$ of injected but otherwise untreated shrimp. Shrimp were kept in culture flasks for 10 days following infection. Cumulative mortality was recorded daily.

\subsection{Quantitative real-time PCR}

Quantitative real-time RT-PCR (qPCR) was performed on an ABI 7500 system as previously described (Labreuche et al., 2009). Amplification efficiencies for all qPCR primers were determined according to Pfaffl and collaborators (Pfaffl et al., 2002) and the specificity of the PCR amplification verified from the melting curve. Each run included the cDNA control, negative controls (total RNA treated with DNase I), and blank controls (water). The relative mRNA expression levels were determined using the two standard curve methodology (QuantiTect ${ }^{\circledR}$ SYBR Green PCR Handbook) and S3A ribosomal protein (BF023924) was used as the internal reference (normaliser) mRNA. Primer sequences are indicated in Table 1.

\subsection{Statistical analyses}

All numerical data were expressed as the mean \pm standard error. Differences in mortality levels between treatments were analyzed by Kaplan-Meier log-rank $x 2$ tests using GraphPad Prism 3.00 for Windows (GraphPad Software, USA) computer software. Oneway analysis of variance (ANOVA) or the Kruskal-Wallis test was used for mRNA expression analysis. These statistical analyses were performed with Statgraphics Plus 5.0 software. 


\section{Results}

\subsection{Identification of RNAi components}

A full-length cDNA of a L. vannamei putative Argonaute was first isolated by PCR and RACE, with an open reading frame (ORF) of $2820 \mathrm{bp}$, a 5' untranslated region of $84 \mathrm{bp}$,

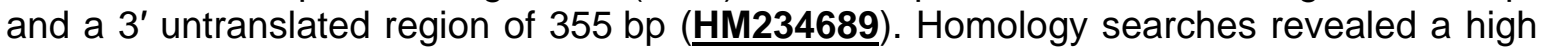
degree of homology between the deduced protein and other Argonaute family proteins, including Penaeus monodon Argonaute 1 Pem-AGO (DQ663629, 99\% overall amino acid identity), Pm ago (DQ343133, 93\% identity) as well as Drosophila Argonaute-1 (NM 166020, 85\% identity). Therefore, this L. vannamei-Argonaute protein was designated Lv-Ago 1. Expressed sequence tag analyses resulted in the identification of three non-overlapping clones (FE096200, FE146474 and FE144758) that showed strong sequence similarities to Argonaute proteins from Caenorhabditis elegans (BlastX E-value $\left.9 \times 10^{-24}\right)$, Gobiocypris rarus $\left(6 \times 10^{-22}\right)$ and $P$. monodon $\left(8 \times 10^{-26}\right)$, respectively. Following reverse transcription of gill RNA, PCR reactions performed with specific primers designed at the 5' and $3^{\prime}$ extremities of each clone indicated that these 3 EST sequences belonged to the same transcript (data not shown). Full-length CDNA cloning by RACEPCR revealed the presence of a $2633 \mathrm{bp}$ transcript (HM234690) containing a $2556 \mathrm{bp}$ ORF and a 5'untranslated region of 77 nucleotides. Following a BlastX search, this L. vannamei Argonaute protein was shown to display higher similarity to $G$. rarus Argonaute 2 (EF636801, 40\% identity) than P. monodon Argonaute 1 Pem-AGO (39\%). Accordingly, this putative protein was designated Lv-Ago 2. Analyses of the amino acid sequence deduced from these two putative Argonaute proteins using the Conserved Domain Search Service (http://www.ncbi.nlm.nih.gov/Structure/cdd/wrpsb.cgi) identified the presence of two distinctive domains, PIWI/Argonaute/Zwille (also named PAZ) and Piwi, that are signature motifs for the Piwi/Argonaute family of proteins (Cerutti et al. 2000). The PAZ domain is involved in dsRNA binding activity, while the Piwi domain displays RNase activity. The PAZ domain of $L V$-ago 1 and $L v$-ago 2 extended from residues 280 to 400, and 240 to 352 respectively, whereas the Piwi domain was located at residues 445-897 and 398-814, respectively (Fig. 1). To study the molecular evolution of LV-ago 1 and LV-ago 2, Argonaute family homologous protein sequences from invertebrate organisms were used to construct a phylogenetic tree, based on Piwi domain alignments (Fig. 2). Argonaute proteins can be divided into four groups: the proteins interacting with trigger-derived sense and antisense RNAs to initiate RNAi (the RNAi pathway), the proteins implicated in the miRNA pathway, the proteins involved in transcriptional silencing, and finally the proteins involved in generation of dsRNA from aberrant RNAs. Phylogenetic tree analysis separated Lv-Ago 1 and Lv-Ago 2 into two clusters, Lv-Ago 1 being clearly orthologous to P. monodon Argonaute 1 (Pem Ago) and more generally to the miRNA class Argonautes, while Lv-Ago 2 clustered on a separate branch from all miRNA class members.

L. vannamei EST database analyses also identified 2 non-overlapping clones (FE073135 and FE152240.1) displaying strong sequence similarities to Sid 1-like proteins from Taeniopygia guttata (BlastX E-value $8 \times 10^{-11}$ ) and Tribolium castaneum (BlastX E-value $4 \times 10^{-26}$ ) respectively. PCR reactions performed with specific primers designed at the $5^{\prime}$ and 3' extremities of each clone indicated that these 2 EST sequences belonged to the same transcript (data not shown). Amplification by 5'-RACE PCR of this L. vannamei putative Sid-1 generated a 2809 bp full-length cDNA with an ORF of 2730 bp encoding a putative protein of 909 amino acids ( $\underline{\mathbf{H M} 234688})$. Blast search revealed that the deduced protein is 
similar to Bos taurus Sid-1 (NM 001024530, 26\% identity, E-value $8 \times 10^{-58}$ ) and Pan troglodytes Sid-1 (XP 001154535, 26\% identity, E-value $\left.7 \times 10^{-57}\right)$. Prediction of transmembrane (TM) helices in the deduced putative structure was performed with TMHMM server version 2.0 (http://www.cbs.dtu.dk/services/TMHMM/). Like C. elegans Sid-1, Lv-Sid-1 was shown to contain 11 TM domains (Fig. 3), with a large (348 amino acids) extracellular N-terminal domain and a 150 amino acid loop residing between the first and second predicted TM helices. A scan of the sequence against the PROSITE database did not identify additional motifs or domains. Phylogenetic analysis of the carboxy-terminal TM domain (corresponding to the TM2-TM11 region) of 15 Sid-1 like proteins demonstrated a close phylogenetic relationship for all mammalian Sid-1 proteins, while Lv-Sid-1 clustered on a separate branch (Fig. 4).

\subsection{Lv-sid-1 and Lv-ago 2 mRNA expression is up-regulated by dsRNA but not by} SiRNAs.

Because $L v$-sid-1, $L v$-ago 1 and $L v$-ago 2 are putative core components of a shrimp RNAi pathway, we investigated whether their expression might be transcriptionally regulated following injection of RNA duplexes of diverse length and specificity. To this end, shrimp were injected with either specific or non-specific siRNAs or dsRNA of varying lengths. As indicated in Fig. 5, Lv-sid-1 mRNA levels were significantly induced in animals challenged with $>50$ bp specific (Fig. $5 \mathrm{~A}$ ) and non-specific dsRNA (Fig. $5 \mathrm{~B}$ ), compared to shrimp injected with saline only $(P<0.05)$. Synthetic siRNAs (specific and non-specific) did not cause any significant variation in Lv-sid-1 mRNA levels, as assessed by comparison with saline-injected animals $(P>0.05)$. As indicated in Fig. 6, 100-bp specific and non-specific dsRNA led to a significant up-regulation of $L v$-ago 2 expression profiles $(P<0.05)$, whereas $L v$-ago 1 mRNA levels remained stable, compared to saline-injected animals, whatever the length and specificity of tested dsRNA. Synthetic siRNAs failed to induce any significant effect on $L v$-ago 1 and $L v$-ago 2 expression levels, independently of their specificity (Fig. 6).

\subsection{Only > 50 bp-dsRNA, but not siRNAs, induce targeted genetic interference and}

\section{general antiviral protection when injected into shrimp.}

Experiments were conducted to explore the influence of dsRNA length on specific depletion of cognate mRNA. To this end, shrimp were injected with either different size dsRNA or synthetic siRNAs targeting the CDP gene. As shown in Fig. 7, injection of genespecific dsRNA of varying lengths (ranging from 50 to $200 \mathrm{bp}$ ) led to a statistically significant depletion of the cognate mRNA in gills, as determined by qPCR (ANOVA, $P<$ 0.05), while none of the 3 CDP-specific siRNAs induced a down-regulation of CDP gene expression when compared to injection of saline only (ANOVA, $P>0.05$ ).

Finally, we investigated the influence of non-specific dsRNA length to mediate antiviral protection during a WSSV challenge. For this experiment, animals were injected with either duck Igv synthetic siRNA or duck Igv dsRNA of varying sizes (ranging from 50 to $200 \mathrm{bp}$ ). Confirming previously reported results (Robalino et al., 2005), non-specific siRNAs completely failed to protect shrimp from viral infection, cumulative mortality for this treatment reaching $100 \%$ at 5 days post injection (dpi) (Fig. 8). All tested dsRNA afforded a statistically significant antiviral protection from WSSV infection $9 \mathrm{dpi}$, compared to 
siRNA-injected and saline-injected shrimp (Kaplan-Meier log-rank $X 2: 62.21, P<0.0001$ ). The degree of protection did not significantly vary with the length of dsRNA injected to the shrimp (Kaplan-Meier log-rank $X 2: 0.4753, P=0.9243$ ).

\section{Discussion}

RNAi-based methodologies and technologies are still in their infancy in penaeid shrimp and some questions need to be addressed before the whole promise of RNAi can be utilized to improve aquaculture. Among these questions, the almost certain role of the RNAi machinery in the observed sequence-specific down-regulation of endogenous or viral gene expression after dsRNA administration remained to be clarified in L. vannamei, as well as the receptor(s) involved in dsRNA uptake. In this study, we report for the first time in a marine crustacean the cloning and characterization of a Sid-1 homologue, LVSid-1, and the identification of two putative shrimp Argonaute, LV-Ago 1 and Lv-Ago 2, a protein family described as the principal protein component of RNA silencing pathways.

\subsection{Shrimp Argonautes, Lv-Ago 1 and Lv-Ago 2, may be implicated in distinct}

\section{pathways.}

The inferred amino acid sequences of $L v$-ago 1 and $L v$-ago 2 cDNAs revealed that these putative proteins possess the two distinctive features of Argonaute family proteins, i.e. a PAZ domain involved in dsRNA binding and a PIWI domain, reported to possess RNase activity. Homology searches indicated that Lv-Ago 1 showed high sequence similarities to Drosophila Argonaute-1, while LV-ago 2 deduced aa sequence displayed higher similarities to Argonaute 2 protein members. Similarly to this observation, several paralogs have been identified in insects, nematodes, mammals and plants, suggesting specific roles associated with each one of them, when they are recruited into the RISC or effector complexes. For instance, among the several Argonaute family proteins characterized in mammals, only Argonaute 2 is catalytically competent and responsible for mRNA cleavage activity (Liu et al., 2004). Of the 27 Argonaute proteins discovered in C. elegans, RDE-1 binds to many classes of small RNAs (Corrêa et al., 2010), while ALG-1 and ALG-2 exclusively bind miRNAs, a class of endogenously produced $\approx 22$-nt RNAs, that associate Argonaute proteins to direct mRNA degradation or translational repression (Grishok et al., 2001). Phylogenetic analyses performed to determine the evolutionary relatedness of these shrimp proteins with invertebrate Argonaute-related genes demonstrated the orthologous relationship of Lv-Ago 1 with miRNA class Argonautes, while Lv-Ago 2 localized to a separate branch. An exclusive association of Argonaute gene family with either the miRNA or RNAi pathway has been reported in many organisms, and we addressed whether $L v$-ago 1 and $L v$-ago 2 display the same functions. If one or both of these shrimp Argonaute proteins was involved in the dsRNA-inducing gene silencing mechanism, their expression would be modified following dsRNA administration, as such regulation has been shown to be important for optimal efficiency of the RNAi pathway (Choudhary et al., 2007). Monitoring $L v$-ago 1 and $L v$-ago 2 transcript accumulation by qPCR following dsRNA injection into shrimp allowed us to demonstrate a strong induction of $L v$-ago 2 mRNA expression only. Taken together, these results suggest i) that these two Argonautes do not play redundant roles in sequence-specific gene silencing, and ii) that Lv-Ago 2 may be specifically implicated in the RNAi pathway. In Penaeus monodon, 
knock-down of Pem-ago (which shows 99\% overall amino acid identity with Lv-Ago 1) with sequence-specific dsRNA was reported to partially reduce the efficiency of RNAi for an endogenous shrimp gene (Dechklar et al., 2008). Because RNAi was still functional at a certain level $(\approx 50 \%$ of the original activity), it was hypothesized that other Argonaute family members may be involved in this mechanism. The data obtained in this work further support this assumption. Interestingly, a conserved D-D-H motif, shown to be essential for the "slicing" activity in the RNase $\mathrm{H}$-related Piwi domain, was identified in both proteins (Rivas et al., 2005) (Fig. 1), indicating that they may both display a catalytic activity. The phylogenetic analysis and the existence of these critical residues for endonucleolytic activity in LV-Ago 1, in relation to the observed lack of induction by exogenous dsRNA and siRNAs, suggest that Lv-Ago 1 may selectively recruit certain classes of small RNA duplexes, as reported in Drosophila (Baumberger and Baulcombe, 2005; Tomari et al., 2007) and in C. elegans (Jannot et al., 2008). Although no confirmed miRNAs have been reported to date in penaeid shrimp, they are known to be widely expressed in metazoa, playing key regulatory roles in embryogenesis, stem cell division, neurogenesis and haematopoietic cell differentiation (Bushati, 2007). Further investigations are thus needed to determine the potential existence and role of miRNAs in shrimp and whether Lv-Ago 1 may be involved in a potential miRNA-directed RNA silencing mechanism.

\subsection{The shrimp Sid-1 homologue, Lv-Sid-1, responds to dsRNA stimulation}

Previous studies in penaeid shrimp have reported the systemic spread of the RNAi effect throughout the entire body, although the mechanistic details of this phenomenon remained undetermined. In animals, two distinct mechanisms responsible for systemic RNAi have been described: a channel-mediated mechanism based on a multispan transmembrane protein called Sid-1 (systemic interference defective) (Winston et al., 2002) and an endocytosis-mediated mechanism based on scavenger-like pattern recognition receptors (Saleh et al., 2006). Using an expressed sequence tag analysis approach in L. vannamei, a $L v$-sid-1 mRNA encoding a putative protein with strong sequence similarity to Sid1 proteins characterized in animals was found. In keeping with this protein family, Lv-Sid-1 was predicted to contain 11 transmembrane domains, suggesting that it may function as a transmembrane channel (Fig. 3). Considering the critical role of this protein in C. elegans, and the occurrence of systemic RNAi in most organisms exhibiting Sid-1 homologues, it has been suggested that import of silencing signals via this protein is an ancient conserved function (Winston et al., 2002). However, recent work in Tribolium castaneum reported 3 sid-1 like genes which did not seem to be required for the systemic RNAi response (Tomoyasu et al., 2008). To provide a clue about $L v$-sid-1 function in shrimp, we therefore analyzed its relative expression following shrimp injection with RNA duplexes. Administration of dsRNA into the shrimp body cavity elicited a substantial increase of $L v$ sid-1 mRNA levels, showing that dsRNA induces the transcriptional activation of this gene, and suggesting thus its potential role as a channel for dsRNA. Knock-down experiments of Lv-Sid-1 message with sequence-specific dsRNA induced mortality in this assay system, up to $80 \%$ shrimp dying within the first 2 days post-injection (data not shown). Interestingly, silencing of other genes obtained from L. vannamei libraries and presumptively associated with the RNAi pathway (like armitage) resulted in a similar lethal phenotype in shrimp (J. Robalino, pers. com.), suggesting that these components, including LV-Sid-1, may be involved in other essential for live functions. Considering these data and the unavailability of clonal cell lines in marine invertebrates, further investigations of Lv-sid-1 molecular properties are needed in in vivo conditions and may require expression in heterologous tissue culture systems (Feinberg and Hunter, 2003). 


\section{3 dsRNA-induced specific gene silencing in $L$. vannamei is length-dependent}

Discrepancies in the ability of siRNAs to promote targeted genetic interference and general antiviral protection have been reported in shrimp (Li et al., 2007; Robalino et al., 2005; Westenberg et al., 2005; Wu et al., 2007; Wu et al., 2008). In this study, we clearly showed that only >50-bp specific dsRNA induced a significant depletion of cognate mRNA. Several hypotheses have been evoked to explain the inconsistencies between these results and other published data, among which the differences between methods used to select and design target sequences for RNAi. However, this size-dependent silencing effect has been reported not only in shrimp, but also in other organisms, and demonstrated to be independent of the nature of siRNA sequences (Feinberg and Hunter, 2003). This observation is confirmed by our experimental data since 3 different siRNAs were tested in this work with the same result. It has also been proposed that the lack of biological activity of siRNAs in shrimp was linked to the existence of mechanisms for uptake of long dsRNA that do not act on very short ones (Robalino et al., 2005; Westenberg et al., 2005). The absence of $L v$-sid-1 transcriptional response observed in this study following siRNA injection into shrimp tends to support this assumption. Interestingly, Shih and collaborators have recently demonstrated in $C$. elegans that the reduced silencing efficiency associated with siRNAs could not be explained by sizeselective transport through Sid-1, but would rather be linked to the fact that these short RNA duplexes are poor substrates for RISC complexes (Shih et al., 2009). Here we found that injection of siRNAs completely failed to induce $L v$-ago 2 expression, further supporting this idea that siRNA may not be incorporated into the shrimp RNAi machinery, explaining thus their observed inability to induce knock-down of the target gene.

\section{4 the non-specific antiviral response to arbitrary dsRNA is length-dependent and}

\section{may rely on RNAi pathway components}

Double-stranded RNA, a molecular structure commonly encountered during the virus replication cycle, is a well-known inducer of innate antiviral immune responses in mammals but also, and more surprisingly, in shrimp (Robalino et al., 2004; Robalino et al., 2007). In vertebrates, dsRNA is sensed by different families of pattern recognition receptors (PRRs), among which the TLRs (Takeuchi and Akira, 2010), and triggers the transcription-based antiviral interferon (IFN) response (Haller et al., 2006). For most of these PRRs, a length dependence was observed for dsRNA to bind to the receptor and elicit innate immunity (Kato et al., 2008; Okahira et al., 2005). Genes encoding homologues of interferons and IFN-regulated genes are absent in sequenced invertebrate genomes, and the mechanistic details of the shrimp immune response to dsRNA are unknown. Data presented here provide evidence for the occurrence of a length-dependent antiviral response in shrimp, and suggest the existence of immune mechanisms analogous, at least to some extent, to those described in vertebrates. Recently, a TLR (IToll) was characterized in L. vannamei, but shown to play no role in dsRNA-induced antiviral immunity (Labreuche et al., 2009). Searches of available EST sequences for other PRRs capable of binding dsRNA have not yet yielded homologues for these components, and further investigations are needed to uncover the mechanisms of this sequenceindependent immunity. In mammals, several studies have demonstrated the existing link between the PKR pathway (a central player in the innate immune response to viral infections known, to be activated by dsRNA in a length-dependent manner), and components of the RNAi machinery (Haase et al., 2005; Laraki et al., 2008). The existence 
of similar interactions between RNAi and innate immunity by dsRNA to mount antiviral protection has also been suspected in shrimp (Robalino et al., 2005). Our study, showing that non-specific long dsRNA trigger the same induction of $L v$-sid-1 and $L v$-ago 2 mRNA expression as sequence-specific dsRNA provides further support to this assumption.

\section{Conclusion}

The results presented in this study expand the biochemical framework for the understanding of RNAi-based mechanisms in shrimp, and reveal, through the identification of a $L V$-ago multigene family, the probable existence of different forms of RNA silencing in this animal model. They also support the idea that the mechanisms involved in dsRNAinduced immunity and RNAi converge to mount an efficient antiviral response in crustacea. Further research is needed to find out the mechanisms influencing the activation and/or switching between these processes but also to what extent selective recruitment of these Argonaute proteins plays a role in shrimp physiology.

\section{Acknowledgments}

This research was funded by awards from the National Science Foundation (MCB0315393; MCB0624271), the National Marine Fisheries Service (NA03NMF472O362), the USDA (NRI-CREES 2006-01605 and the U.S. Marine Shrimp Farming Program), by a Marine Genomics fellowship support from the College of Charleston to A.V. and through the support of the NOAA Center of Excellence in Oceans and Human Health at the Hollings Marine Laboratory. This is publication \# for the Marine Genomics Program of the Marine Biomedicine and Environmental Sciences program at MUSC and \# from the Marine Resources Division of the South Carolina Department of Natural Resources. We warmly thank members of the Marine Infectious Disease Laboratory at the South Carolina Department of Natural Resources for their help with rearing and challenge assays of shrimp. Any opinions, findings, and conclusions or recommendations expressed in this material are those of the author(s) and do not necessarily reflect the views of the supporting bodies mentioned herein.

\section{References}

Grishok, A., Pasquinelli, A.E., Conte, D., Li, N., Parrish, S., Ha, I., Baillie, D.L., Fire, A., Ruvkun, G., and Mello, C.C., 2001. Genes and Mechanisms Related to RNA Interference Regulate Expression of the Small Temporal RNAs that Control C. elegans Developmental Timing. Cell 106(1), 23-34.

Riddle, N.C., and Elgin, S.C., 2008. A role for RNAi in heterochromatin formation in Drosophila. Curr Top Microbiol Immunol. 320, 185-209.

Aravin, A.A., Hannon, G.J., and Brennecke, J., 2007. The piwi-piRNA pathway provides an adaptive defense in the transposon arms race. Science 318, 761-764.

Li, H.W., and Ding, S.W., 2005. Antiviral silencing in animals. FEBS Lett. 579, 5965-5973. Campbell, T.N., and Choy, F.Y., 2005. RNA interference, Past, present and future. Curr Issues Mol Biol. 7(1), 1-6. 
Hui, J.H., Tobe, S.S., and Chan, S.M., 2008. Characterization of the putative farnesoic acid O-methyltransferase (LvFAMeT) cDNA from white shrimp, Litopenaeus vannamei, Evidence for its role in molting. Peptides 29, 252-260.

Tiu, S.H., He, J.G., and Chan, S.M., 2007. The LVCHH-ITP gene of the shrimp (Litopenaeus vannamei) produces a widely expressed putative ion transport peptide (LvITP) for osmo-regulation. Gene 396, 226-235.

Treerattrakool, S., Panyim, S., Chan, S.M., Withyachumnarnkul, B., and Udomkit, A., 2008. Molecular characterization of gonad-inhibiting hormone of Penaeus monodon and elucidation of its inhibitory role in vitellogenin expression by RNA interference. FEBS J. 275, 970-980.

Lugo, J.M., Morera, Y., Rodriguez, T., Huberman, A., Ramos, L., and Estrada, M.P., 2006. Molecular cloning and characterization of the crustacean hyperglycemic hormone cDNA from Litopenaeus schmitti. Functional analysis by double-stranded RNA interference technique. FEBS J. 273, 5669-5677.

de la Vega, E., O'Leary, N.A., Shockey, J.E., Robalino, J., Payne, C., Browdy, C.L., Warr, G.W., Gross, P.S., 2008. Anti-lipopolysaccharide factor in Litopenaeus vannamei (LvALF), a broad spectrum antimicrobial peptide essential for shrimp immunity against bacterial and fungal infection. Mol Immunol. 45 (7), 1916-25.

Shockey, J.E., O'Leary, N.A., de la Vega, E., Browdy, C.L., Baatz, J.E., Gross, P.S., 2009. The role of crustins in Litopenaeus vannamei in response to infection with shrimp pathogens: An in vivo approach. Dev Comp Immunol. 33 (5), 668-73

Robalino, J., Bartlett, T., Shepard, E., Prior, S., Jaramillo, G., Scura, E., Chapman, R.W., Gross, P.S., Browdy, C.L., and Warr, G.W., 2005. Double-stranded RNA induces sequence-specific antiviral silencing in addition to nonspecific immunity in a marine shrimp, convergence of RNA interference and innate immunity in the invertebrate antiviral response? J Virol 79(21), 13561-13571.

Shekhar, M., and Lu, Y., 2009. Application of nucleic-acid-based therapeutics for viral infections in shrimp aquaculture. Mar Biotechnol (NY). 11(1), 1-9.

Robalino, J., Browdy, C.L., Prior, S., Metz, A., Parnell, P., Gross, P., and Warr, G., 2004. Induction of antiviral immunity by double-stranded RNA in a marine invertebrate. $\mathrm{J}$ Virol. 78(19), 10442-10448.

Dechklar, M., Udomkit, A., and Panyim, S., 2008. Characterization of Argonaute cDNA from Penaeus monodon and implication of its role in RNA interference. Biochem Biophys Res Commun. 367(4), 768-774.

Unajak, S., Boonsaeng, V., and Jitrapakdee, S., 2006. Isolation and characterization of cDNA encoding Argonaute, a component of RNA silencing in shrimp (Penaeus monodon). Comp Biochem Physiol B Biochem Mol Biol. 145(2), 179-187.

Su, J., Oanh, D.T., Lyons, R.E., Leeton, L., van Hulten, M.C., Tan, S.H., Song, L., Rajendran, K.V., and Walker, P.J., 2008. A key gene of the RNA interference pathway in the black tiger shrimp, Penaeus monodon, identification and functional characterisation of Dicer-1. Fish Shellfish Immunol. 24(2), 223-233.

Li, D.F., Zhang, M.C., Yang, H.J., Zhu, Y.B., and Xu, X., 2007. Beta-integrin mediates WSSV infection. Virology 368(1), 122-132.

Westenberg, M., Heinhuis, B., Zuidema, D., and Vlak, J.M., 2005. siRNA injection induces sequence-independent protection in Penaeus monodon against white spot syndrome virus. Virus Res. 114(1-2), 133-139.

Wu, Y., Lu, L., Yang, L.S., Weng, S.P., Chan, S.M., and He, J.G., 2007. Inhibition of white spot syndrome virus in Litopenaeus vannamei shrimp by sequence-specific siRNA. Aquaculture 271, 21-30. 
Wu, W., Zong, R., Xu, J., and Zhang, X. 2008. Antiviral phagocytosis is regulated by a novel Rab-dependent complex in shrimp Penaeus japonicus. J Proteome Res. 7(1), 424431.

O'Leary, N.A., Trent III, H.F., Robalino, J., Peck, M.E.T., McKillen, D.J., Gross, P.S., 2006. Analysis of multiple tissue-specific cDNA libraries from the Pacific white leg shrimp, Litopenaeus vannamei. Int. Comp. Biol. 46, 931-939

Altschul, S.F., Madden, T.L., Schaffer, A.A., Zhang, J., Zhang, Z., Miller, W., Lipman, D.J., 1997. Gapped BLAST and PSI-BLAST, a new generation of protein database search programs. Nucl. Acids Res. 25, 3389-3402

Tamura, K., Dudley, J., Nei, M., and Kumar, S., 2007. MEGA4 : Molecular Evolutionary Genetics Analysis (MEGA) software version 4.0. Mol Biol Evol. 24, 1596-1599.

Prior, S., Browdy, C.L., Shepard, E.F., Laramore, R., and Parnell, P.G., 2003. Controlled bioassay systems for determination of lethal infective doses of tissue homogenates containing Taura syndrome or white spot syndrome virus. Dis. Aquat. Organ. 54, 89-96.

Labreuche, Y., O'Leary, N.A., de la Vega, E., Veloso, A., Gross, P.S., Chapman, R.W., Browdy, C.L., and Warr, G.W., 2009. Lack of evidence for Litopenaeus vannamei Toll receptor (IToll) involvement in activation of sequence-independent antiviral immunity in shrimp. Dev Comp Immunol. 33(7), 806-810.

Pfaffl, M.W., Horgan, G.W., and Dempfle, L., 2002. Relative expression software tool (REST(C) for group-wise comparison and statistical analysis of relative expression results in real-time PCR. Nucl. Acid Res. 30(9), e36.

Cerutti, L., Mian, N., and Bateman, A., 2000. Domains in gene silencing and cell differentiation proteins: the novel PAZ domain and redefinition of the Piwi domain. Trends Biochem Sci. 25(10), 481-482.

Liu, J., Carmell, M., Rivas, F., Marsden, C., Thomson, J., Song, J., Hammond, S., JoshuaTor, L., and Hannon, G., 2004. Argonaute2 is the catalytic engine of mammalian RNAi. Science 305(5689), 1437-1441.

Corrêa, R., Steiner, F., Berezikov, E., and Ketting, R., 2010. MicroRNA-directed siRNA biogenesis in Caenorhabditis elegans. PLoS Genet. 6(4), e1000903.

Choudhary, S., Lee, H., Maiti, M., He, Q., Cheng, P., Liu, Q., and Liu, Y., 2007. A doublestranded-RNA response program important for RNA interference efficiency. Mol Cell Biol. 27(11), 3995-4005.

Rivas, F., Tolia, N., Song, J., Aragon, J., Liu, J., Hannon, G., and Joshua-Tor, L., 2005. Purified Argonaute2 and an siRNA form recombinant human RISC. Nat Struct Mol Biol. 12(4), 340-349.

Baumberger, N., and Baulcombe, D., 2005. Arabidopsis ARGONAUTE1 is an RNA Slicer that selectively recruits microRNAs and short interfering RNAs. Proc Natl Acad Sci U S A. 102(33), 11928-11933.

Tomari, Y., Du, T., and Zamore, P., 2007. Sorting of Drosophila small silencing RNAs. Cell 130(2), 299-308.

Jannot, G., Boisvert, M., Banville, I., and Simard, M., 2008. Two molecular features contribute to the Argonaute specificity for the microRNA and RNAi pathways in C. elegans. RNA 14(5), 829-835.

Bushati, N., 2007. MicroRNA Functions. Ann Rev Cell Dev Biol. 23, 175-205.

Winston, W., Molodowitch, C., and Hunter, C., 2002. Systemic RNAi in C. elegans requires the putative transmembrane protein SID-1. Science 295(5564), 2456-2459.

Saleh, M., van Rij, R., Hekele, A., Gillis, A., Foley, E., O'Farrell, P., and Andino, R., 2006. The endocytic pathway mediates cell entry of dsRNA to induce RNAi silencing. Nat Cell Biol. 8(8), 793-802. 
Tomoyasu, Y., Miller, S., Tomita, S., Schoppmeier, M., Grossmann, D., and Bucher, G., 2008. Exploring systemic RNA interference in insects: a genome-wide survey for RNAi genes in Tribolium. Genome Biol. 9(1), R10.

Feinberg, E.H., and Hunter, C.P., 2003. Transport of dsRNA into cells by the transmembrane protein SID-1. Science 301(5639), 1545-1547.

Shih, J., Fitzgerald, M., Sutherlin, M., and Hunter, C., 2009. The SID-1 double-stranded RNA transporter is not selective for dsRNA length. RNA 15(3), 384-390.

Robalino, J., Bartlett, T.C., Chapman, R.W., Gross, P.S., Browdy, C.L., and Warr, G.W., 2007. Double-stranded RNA and antiviral immunity in marine shrimp: inducible host mechanisms and evidence for the evolution of viral counter-responses. Dev Comp Immunol. 31(6), 539-547.

Takeuchi, O., and Akira, S., 2010. Pattern recognition receptors and inflammation. Cell 140(6), 805-820.

Haller, O., Kochs, G., Weber, F., 2006. The interferon response circuit: induction and suppression by pathogenic viruses. Virology. 344 (1),119-30.

Kato, H., Takeuchi, O., Mikamo-Satoh, E., Hirai, R., Kawai, T., Matsushita, K., Hiiragi, A., Dermody, T.S., Fujita, T., and Akira, S., 2008. Length-dependent recognition of doublestranded ribonucleic acids by retinoic acid-inducible gene-I and melanoma differentiationassociated gene 5. J Exp Med. 205(7), 1601-1610.

Okahira, S., Nishikawa, F., Nishikawa, S., Akazawa, T., Seya, T., and Matsumoto, M., 2005. Interferon- $\beta$ Induction Through Toll-Like Receptor 3 Depends on Double-Stranded RNA Structure. DNA Cell Biol. 24(10), 614-623.

Haase, A., Jaskiewicz, L., Zhang, H., Lainé, S., Sack, R., Gatignol, A., and Filipowicz, W., 2005. TRBP, a regulator of cellular PKR and HIV-1 virus expression, interacts with Dicer and functions in RNA silencing. EMBO Rep. 6(10), 961-967.

Laraki, G., Clerzius, G., Daher, A., Melendez-Peña, C., Daniels, S., and Gatignol, A., 2008. Interactions between the double-stranded RNA-binding proteins TRBP and PACT define the Medipal domain that mediates protein-protein interactions. RNA Biol. 5(2), 92103. 


\section{Figures}

Figure 1

Hs Ago 2 Mm Ago 2

Bt Ago 2 XI Ago 2 Gr Ago 2 Lv Ago 1 Lv Ago 2 Dm Ago 2

Hs Ago 2 Mm Ago 2 Bt Ago 2 $\mathrm{Xl}$ Ago 2 Gr Ago 2 Lv Ago 1 Lv Ago 2 Dm Ago 2

Hs_Ago 2 Mm_Ago 2 Bt_Ago 2 $\mathrm{XI}$ _Ago 2 Gr_Ago 2 Lv_Ago 1 Lv_Ago 2 Dm_Ago 2

Hs Ago 2 Mm Ago 2 Bt Ago 2 $\mathrm{Xl}$ Ago 2 Gr Ago 2 LV Ago 1 Lv Ago 2 Dm Ago 2

Hs Ago 2 Mm Ago 2 Bt Ago 2 $\mathrm{Xl}$ Ago 2 Gr Ago 2 LV Ago 1 Lv Ago 2 Dm Ago 2

Hs Ago 2 Mm Ago 2 Bt Ago 2 $\mathrm{Xl}$ Ago 2 Gr Ago 2 LV Ago 1 Lv Ago 2 Dm Ago 2

Hs Ago 2 $\mathrm{Mm}$ Ago 2 Bt Ago 2 $\mathrm{Xl}$ Ago 2 Gr Ago 2 $\mathrm{Lv}$ Ago 1 Lv Ago 2 Dm Ago 2

Hs Ago 2
PYVREFGIMVKDEMTDVTGRVLOPP S I LYGGRNKA IATPVOGVWDMRNKOFHTG---IEI PYVREFGIMVKDEMTDVTGRVLQPP S I LYGGRNKA IATPVQGVWDMRNKQFHTG---IEI PYVREF GIMVKDEMTDVTGRVLQPP S I LYGGRNKA IA TPVQGVWDMRNKQFHTG---IE I PFVREF GIMVKDDMTDVTGRVLQP P I I YGGRSKA IATPVQGVWDMRNKQF HTG---IEI PYVREFGVMVRDEMTEVNGRVLOAP S I LYGGRNKA IATPVOGVWDMRNKOFHTG---IEI PYMQEFGLTISTAMMEVRGRVLPP P KLQYGGRTKQQALP NQGVWDMRGKQFFTG---VEI PLMRQLEFTVSDRPVEMNGRVLPAPNLKMKDG---TVLPEKGVWEAWNREFFKG---AT I PTISRFGIRIANDF IVVSTRVLSP PQVEYHSKRFTMVKN--GSWRMDGMKF LEPKPKAHK

KVWA IACFAPQRQCTEVHLKSFTEQLRKI SRDAGMP IQGQP CFCKYAQGADSVEPMFRHL KVWA IACFAP QRQCTEVHLKSF TEQLRKI SRDAGMP IQGQP CFCKYAQGAD SVEPMFRHL KVWAIACFAPQRQCTEVHLKSF TEQLRKI SRDAGMP IQGQP CFCKYAQGADSVEPMFRHL KVWA IACF APQRQCTEVHLKTF TEQLRKI SRDAGMP IQGQP CF CKYAQGAD SVEPMFRHL KVWA IACF APQROCTELLLKAF TDOLRKI SRDAGMP IOGQP CFCKYAQGADSVEPMFKHL RVWAVACF AP QRTVREDALRNF TQQLQK I SNDAGMP I I GQP CFCKYANGP DQVEPMFRYL ETWAVINYD--KFTAQKDVWAF LNSLLKMAKERGMIMNDP----VKIMDGNAPEKDFPKI CAVLYCDPRSGRKMNYTQLNDFGNLI I SQGKAVNI SLDSDVTYRPFTDDERSLDT IFADL

KNTYAGLQLVVVILPG-KTPVYAEVKRVGDTVLGMATQCVQMKNVQRTTP-QTLSNLCLK KNTYAGLQLVVVILPG-KTPVYAEVKRVGDTVLGMATQCVQMKNVQRTTP-QTLSNLCLK KNTYAGLQLVVVILPG-KTPVYAEVKRVGDTVLGMATQCVQMKNVQRTTP-QTLSNLWLK KNTYTGLQLVVVILPG-KTPVYAEVKRVGDTVLGMATQCVQMKNVQRTTP-QTLSNLCLK KYTYQGLQLVVVILPG-KTPVYAEVKRVGDTVLGMATQCVQVKNVQKTTP-QTLSNLCLK KSTFTGLQLVCVVLPG-KTPVYAEVKRVGDTVLGMATQCVQAKNVNKTSP-QTLSNLCLK MKDFKGIQMI LVNLP SKKGDKYGRVKKMGDREF SVVTQC I LSKTLKNP KP -ATVNNVLLK KRSQHDLA IVI IPQFR---ISYDT IKQKAELQHG I LTQC I KQF TVERKCNNQT I GN I LLK INVKLGGVNNILLPQGRPPVFQQPVIFLGADVTHPPAGDGK-KP SIAAVVGSMDAHPNRY INVKLGGVNN I LLP QGRP PVFQQPVIF LGADVTHP PAGD GK-KP S IAAVVGSMDAHP NRY INVKLGGVNN I LLPQGRPPVFQQPVIFLGADVTHPPAGDGK-KP S IAAVVGSMDAHPNRY INVKLGGVNN I LLPQGRP PVFQQPVIF LGADVTHPPAGDGK-KP S IAAVVGSMDAHPNRY INVKLGGVNN I LLPQGRP LVFQQPVIFLGADVTHPPAGDGK-KP S IAAVVGSMDAHP SRY INVKLGG INS I LVP GIRP KVFNEPVIF LGADVTHPPAGDNK-KP S IAAVVGSMDAHP SRY INGKMGGVNNTLGRESSTF ILTSPVMIMGADVNHP PADDRKGTP SLAAVVGSMDCFASNY INSKLNG INHK I KDDP RLPMMKN-TMY I GADVTHP SP DQRE-IP SVVGVAASHDPYGASY

CATVRVQQHR-------------------------QE I I QDLAAMVRELLIQFYKSTR CATVRVQQHR--------------------------QEI IQDLAAMVRELLIQFYKSTR CATVRVQQHR--------------------------QE I IQDLAAMVRELLIQFYKSTR CATVRVQQHR--------------------------QEI I QDLSAMVRELLIQFYKSTR CATVRVQQHR---------------------------QD I IQDLATMVRELLIQFYKSTR AATVRVQQHRQNGSTTQGQSASDGSRPRQLTFARTAHDEVIQELSSMVKELLIQFYKSTR AAQVRQQI SC------------------------KEI IQDLKEMTRNLLIAFFRKTG NMQYRLQRGA------------------------LEE IEDMF S I T LEHLRVYKEYRN

FKPTRI IFYRDGVSEGQFQQVLHHELLAIREAC IKLEKDYOP GITF IVVOKRHHTRLFCT FKP TRI IFYRDGVSEGQFQQVLHHELLA IREAC I KLEKDYQP G I TF IVVQKRHHTRLFCT FKPTRI IFYRDGVSEGOFOOVLHHELLA IREAC I KLEKDYOPGITF IVVOKRHHTRLFCT FKP TRI IFYRDGVSEGQF QQVLHHELLA IREAC IKLEKDYQP GI TF IVVQKRHHTRLFCT FKP TRI I YYRD GI SEGQFNQVLQHELLA I REAC I KLEKDYQP GITFVVVQKRHHTRLFCM FKPNRI I LYRDGVSEGQFQTVLQHELTAMREAC I KLEADYKP GI TY IAVQKRHHTRLFCS KKPERL IMFRDGVSESQFYTVLGYELKAMREACKSLQQDYKP GMTF IVVQKRHHTRLFCD AYPDH I IYYRDGVSDGQFPKIKNEELRCIKQACDKVG--CKPKICCVIVVKRHHTRFFPS

DKNERVGKSGNIPAGTTVDTKITHP TEFDFYLCSHAGIQGTSRP SHYHVLWDDNRF S SDE DKNERVGKSGNIPAGTTVDTKI THP TEFDFYLCSHAGIQGT SRP S HYHVLWDDNRF S SDE DKNERVGKSGNIPAGTTVDTKI THP TEFDFYLCSHAGIQGT SRP SHYHVLWDDNRF S SDE DRNERVGKS GNIPAGTTVDTKITHP SEFDFYLCSHAGIQGTSRP SHYHVLWDDNRF SSDE DRNERVGKSGNIPAGTTVDTKITHP SEFDFYLCSHAGIQGT SRP SHYHVLWDDNHFTSDE DKKEQSGKS GNIPAGTTVDVGI THP TEFDFYLCSHQG IQGTSRP SHYHVLWDDNHFDSDE DK-DGI GRS KNVP P GT IVDQI I THP SE IDFYLCSHQG I LGT SKP THYRVLWDDNDMTMDQ GDVTTSNKFNNVDP GTVVDRT IVHPNEMQF FMVSHQA IQGTAKP TRYNVIENTGNLD IDL LQILTYQLCHTYVRCTRSVSIPAPAYYA $\bullet$ HLVAFRARYHL 


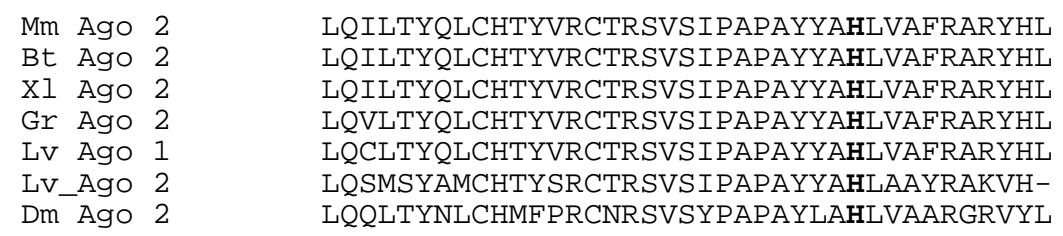

Figure 1. Multiple alignment of the catalytic center of the PIWI domains from the shrimp Argonaute LV-Ago 1 and LV-Ago 2 and representative Ago 2 homologous proteins by ClustalW. The position of the $\mathrm{Mg}^{2+}$ coordinating residues in the $\mathrm{DDH}$ motif, critical for slicing activity, are indicated in bold and marked with a solid circle $(\bullet)$. GenBank accession number are : Drosophila melanogaster, Dm-Ago 2 (Q9VUQ5); Mus musculus, Mm Ago 2 (NP 694818.3); Bos taurus, Bt Ago 2 (NP 991363.1); Xenopus laevis, XI Ago 2 (NP 001086988.1); Homo sapiens, Hs Ago 2 (NP 036286) and Gobiocypris rarus, Gr Ago 2 (ABV22635). 


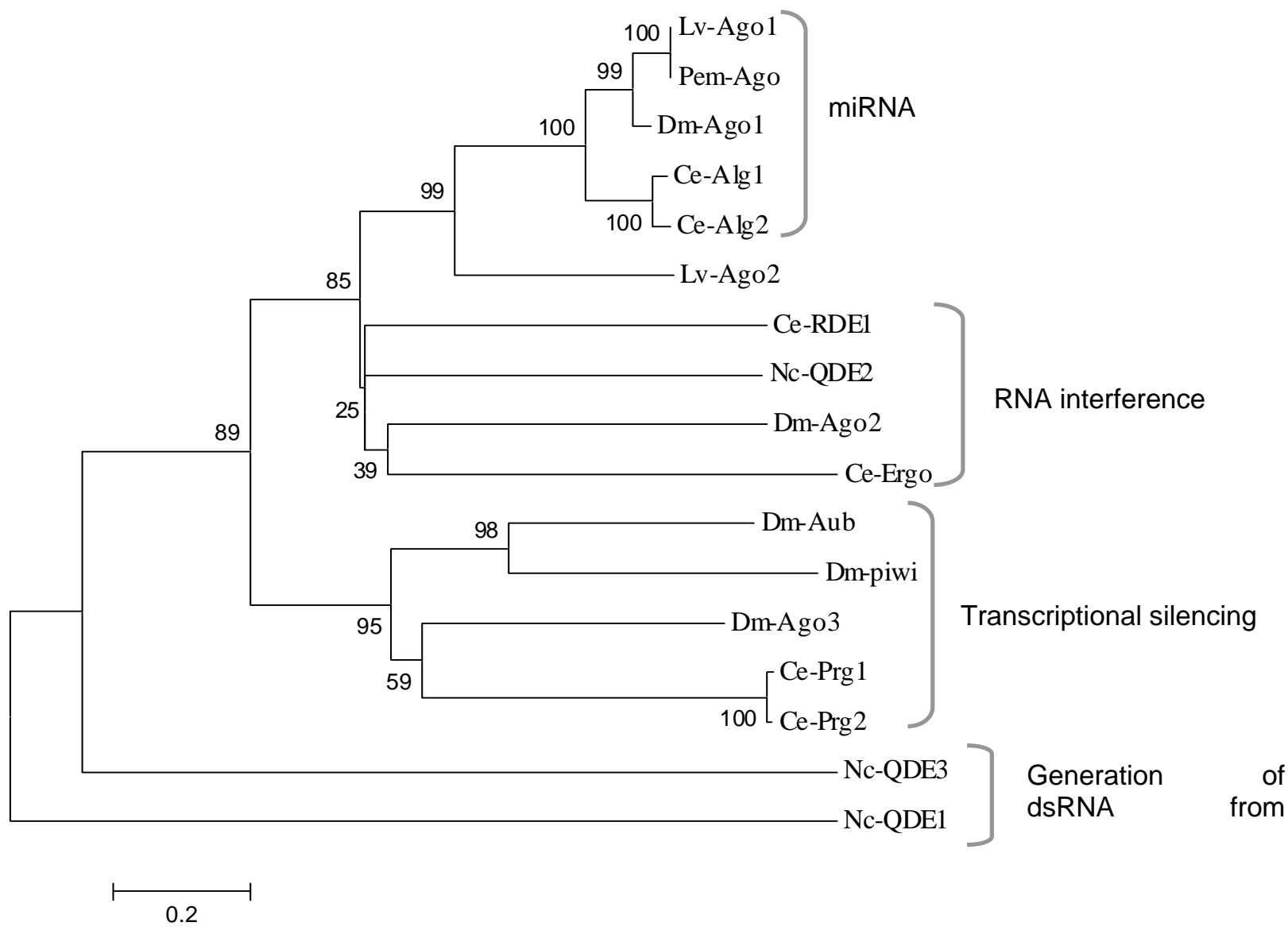

Figure 2. Phylogenetic analysis of Argonaute proteins. Multiple alignments were created and curated in MEGA 4.0. The Neighbor-Joining tree is based on the alignment of the conserved PIWI domain. The tree is drawn to scale, with branch lengths in the same units as those of the evolutionary distances used to infer the phylogenetic tree. GenBank accession number are : Drosophila melanogaster, Dm-Ago 1 (GenBank acc. no. BAA88078), Dm-Ago 2 (Q9VUQ5), Dm-Ago 3 (EF688531), Dm-Aub (CAA64320.1), DmPiwi (AAD08705); Caenorhabditis elegans, Ce-Alg 1 (NP 510322.2), Ce-Alg 2 (NP 493837), Ce-RDE 1 (AAF06159.1), Ce-Ergo (NP 503362), Ce-Prg 1 (NP 492121), Ce-Prg 2 (NP 500944); Neurospora crassa, Nc-QDE 1 (CAB42634), Nc-QDE 2 (AAF43641.1), NC-QDE 3 (AAF31695.1). 
Figure 3

\begin{tabular}{|c|c|c|}
\hline Ce-Sid-1 & - - - - - - MIRVYLIILMHLVIG - LTQNNSTTPSPIITSS - - NSSVLVFEISSKMKMIEK & 49 \\
\hline LV-Sid-1 & MMAPNHRGLSLTILLLLYHGVSGSIPEPPPTTPDEIADTSTETTAITTLETTMKTTPIQT & 60 \\
\hline Ce-Sid-1 & KLEANTVHVLRLELDQSFILDL - - - - TKVAAEIVDSSKYSKEDGVILEVTVSNGRDSFL & 104 \\
\hline LV-Sid-1 & TTTVTTTPVTSTATTDEPVTDIPIQPETDCQAFIPKSGKCRFSKAQKVNISASNPCLFKC & 120 \\
\hline Ce-Sid-1 & LKLPTVYPNLKLYTDGKLLNPLVEQDFGAHRKRHRIG - - - - - - DPHFHQNLIVTVQSR & 156 \\
\hline LV-Sid-1 & HYNPAELSPIRFEVHLTYKHPAQNPTFVTVKQRFFISSWTLPILFPDHGENQKFTSIEKM & 180 \\
\hline Ce-Sid-1 & LNADIDYR - - - - LHVTHLDRAQYDFLKFKTGQTTKTLSNQ - - - KLTFVKPIGFFLNCS & 207 \\
\hline LV-Sid-1 & LCPPTNLQNETLEFYLTTESTQNISFILGVSNQSYVLSMGDNVTVKATPVSPWVKLFKWD & 240 \\
\hline Ce-Sid-1 & EQNISQFHVTLYSEDDICANLITVPANESIYDRSVISDKTHNRRVLSFTKRADIFFTETE & 267 \\
\hline LV-Sid-1 & KEDSILVTADSRDNSDTVCSILALQNAKCPVYADEAEVRAGGTQFQTFTSRAGMVARR - - & 298 \\
\hline Ce-Sid-1 & ISMFKSFRIFVFIAPDDSGCSTNTSRKSFNEKKKISFEFKKLENQSYAVPTALMMIFLTT & 327 \\
\hline LV-Sid-1 & ENFPDGVHIIVVPLPDDDPCTLAFSERANHTSRQKSVILQVYNHATIASTWYVFLLTAGA & 358 \\
\hline Ce-Sid-1 & PCLLFLPIVINIIKNSRKLAPSQSNLIS - - - - - - - - - - - - - FSPVP & 360 \\
\hline LV-Sid-1 & MATVISSFTALSIRMIRRNLTSETVAVEDEDERSLLGESGHSGTHGRIRVEEMAGVSVLS & 418 \\
\hline Ce-Sid-1 & SEQRDMDLSHDEQQNTSSELENNGEIPAAENQIVEEITAENQ - ETSVEEGNREIQVKIPL & 419 \\
\hline LV-Sid-1 & GGEVGGTMSEGSRREGVSQERPFVSASLSDGHLSRNVSNEPYGRLQIDNGSRDLQPLPYA & 478 \\
\hline Ce-Sid-1 & KQDSLSLHGQMLQYP- - - - - - - - - - - - - - - - - VAIILPVLM & 443 \\
\hline LV-Sid-1 & VPSTYAPHHAVLNFSASFNPRLVCWWKRLAVYELRTADAQVAEIGFQNNVLIMAVFTALP & 538 \\
\hline Ce-Sid-1 & HTAIEFHKWTTSTMANRDEMCFHNHACARPLGELRAWNNIITNIGYTLYGAIFIVLSICR & 503 \\
\hline LV-Sid-1 & TTELVRSYLKLLLYHGQEDQCFFNSRCLTAFGTLPDFARVFTNIGYLLCGAAFI I IVKEH & 598 \\
\hline Ce-Sid-1 & R- - - - - - GRHEYSHVFGTYECTLLDVTIGVFMVLQSIASATYHICPSDVAFQFDTPCIQ & 556 \\
\hline LV-Sid-1 & KKFTENILRQYGANNSVGVSRHYGLFMSVGYGLFIQGVMSSLYHTCPNSVTIRFDMMFVY & 658 \\
\hline Ce-Sid-1 & VICGLLMVRQWFVRH -ESPSPAYTNILLVGVVSLNFLISAFSKTSYVRFIIAVIHVIVVG & 615 \\
\hline LV-Sid-1 & VVAVAAVVSMWGFRHGDVTHHVYPTMVMVGMILLMAEAREWVSQAAFWTVLSLCYVFLMV & 718 \\
\hline Ce-Sid-1 & S- - - - - - - - ICLAKERSLGSEKLKTRFFIMAFSMG - - - - - - NFA & 645 \\
\hline LV-Sid-1 & TNTILLTKYGVWSFSPYKMLMVWKGWRPVAEKLRNELWGSATTAKPLQIVRIVIGLVVNS & 778 \\
\hline Ce-Sid-1 & AIVMYLTLSAFHLNQIATYCFIINCIMYLMYYGCMKVLHSERITSKAKLCGALSLLAWAV & 705 \\
\hline LV-Sid-1 & AIILFGCLADPNIYSYILMVCLINMGLYFLNYVIAKICERESVRALPSIALGISLILWIL & 838 \\
\hline Ce-Sid-1 & AGFFFFQDDTDWTRSAAASRALNKPCLLLGFFGSHDLWHIFGALAGLFTFIFVSFVDDDL & 765 \\
\hline LV-Sid-1 & ALAAFFFHSTDPEASPSMSRAKNSPCEFFGVFDTHDAWHLMSALALFTFFVGILTLDDDL & 898 \\
\hline Ce-Sid-1 & INTRKTSINIF 776 & \\
\hline LV-Sid-1 & CHTRSDKIHVF $9 \odot 9$ & \\
\hline
\end{tabular}

Figure 3. Alignment of Sid-1 transmembrane proteins. Predicted transmembrane domains

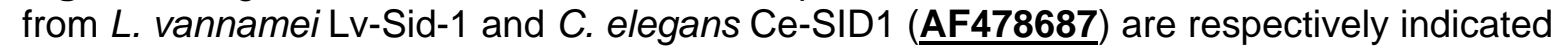
in gray and in green. Numbers indicated on the right side represent the amino acid position in the corresponding species. 
Figure 4

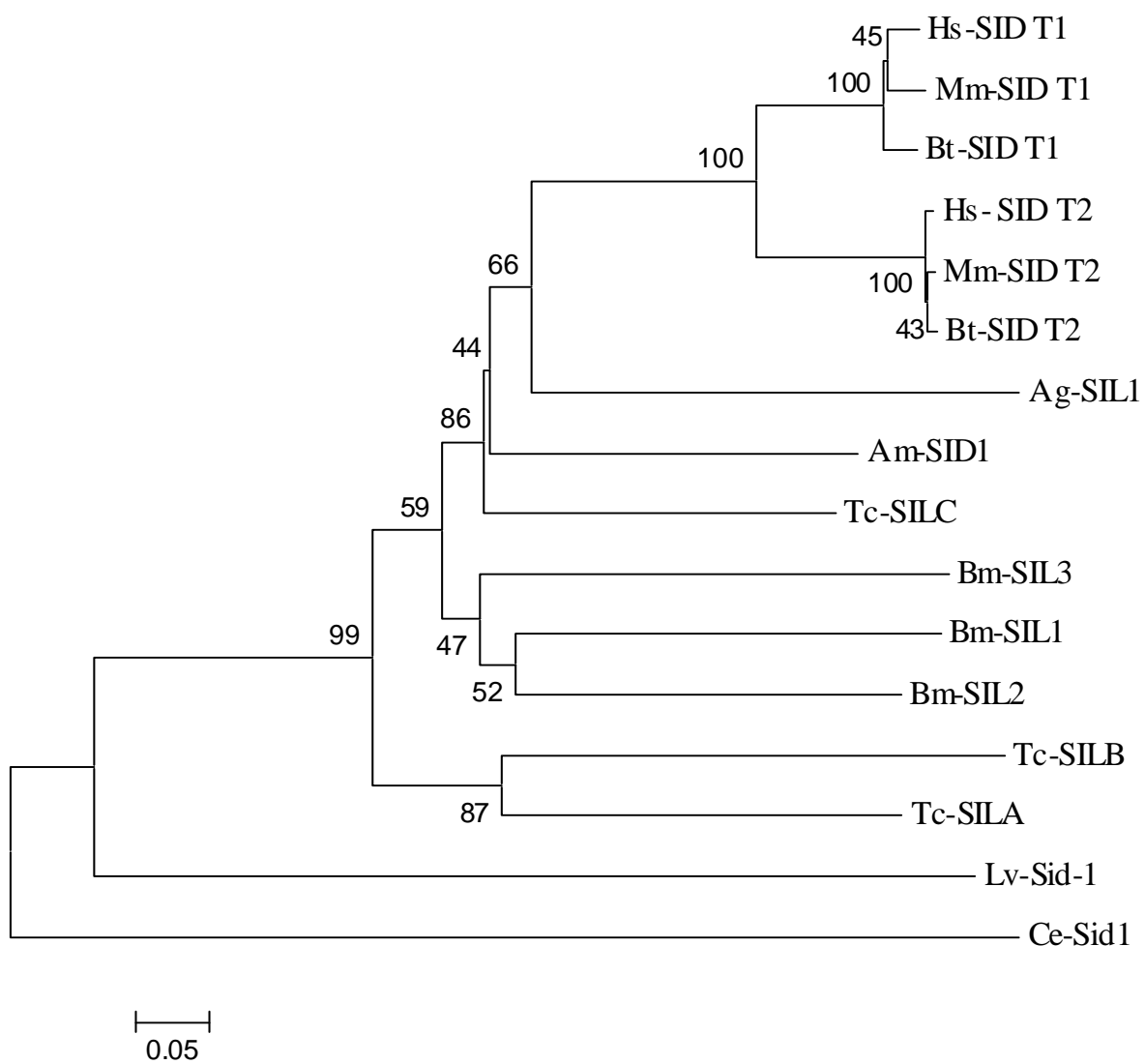

Figure 4. Phylogenetic tree based on amino acid sequences of multiple transmembrane (TM) domain (corresponding to TM2-TM11 portion of $C$. elegans Sid-1) from Sid-1-like genes. GenBank accession number are : Homo sapiens, Hs-SIDT1 (GenBank acc. no. AAI17223.1), Hs-SIDT2 (AAI14523.1); Mus musculus, Mm-SIDT1 (AAH25888.1), MmSIDT2 (AAH06873.1); Bos Taurus, Bt-SIDT1 (XP 585013.3), Bt-SIDT2 (NP 001019701.2); Aphis gossypii, Ag-SIL1 (EF533711); Apis mellifera, Am-SID1 (XP 395167.3); Tribolium castaneum, TC-SILA (NP 001099012.1), TC-SILB (NP 001103253.1), TC-SILC (NP 001099128.1); Bombyx mori, Bm-SIL1 (BAF95805.1), Bm-SIL2 (BAF95807.1), Bm-SIL3 (BAF95806.1); C. elegans, Ce-SID1 (AF478687) 
Figure 5
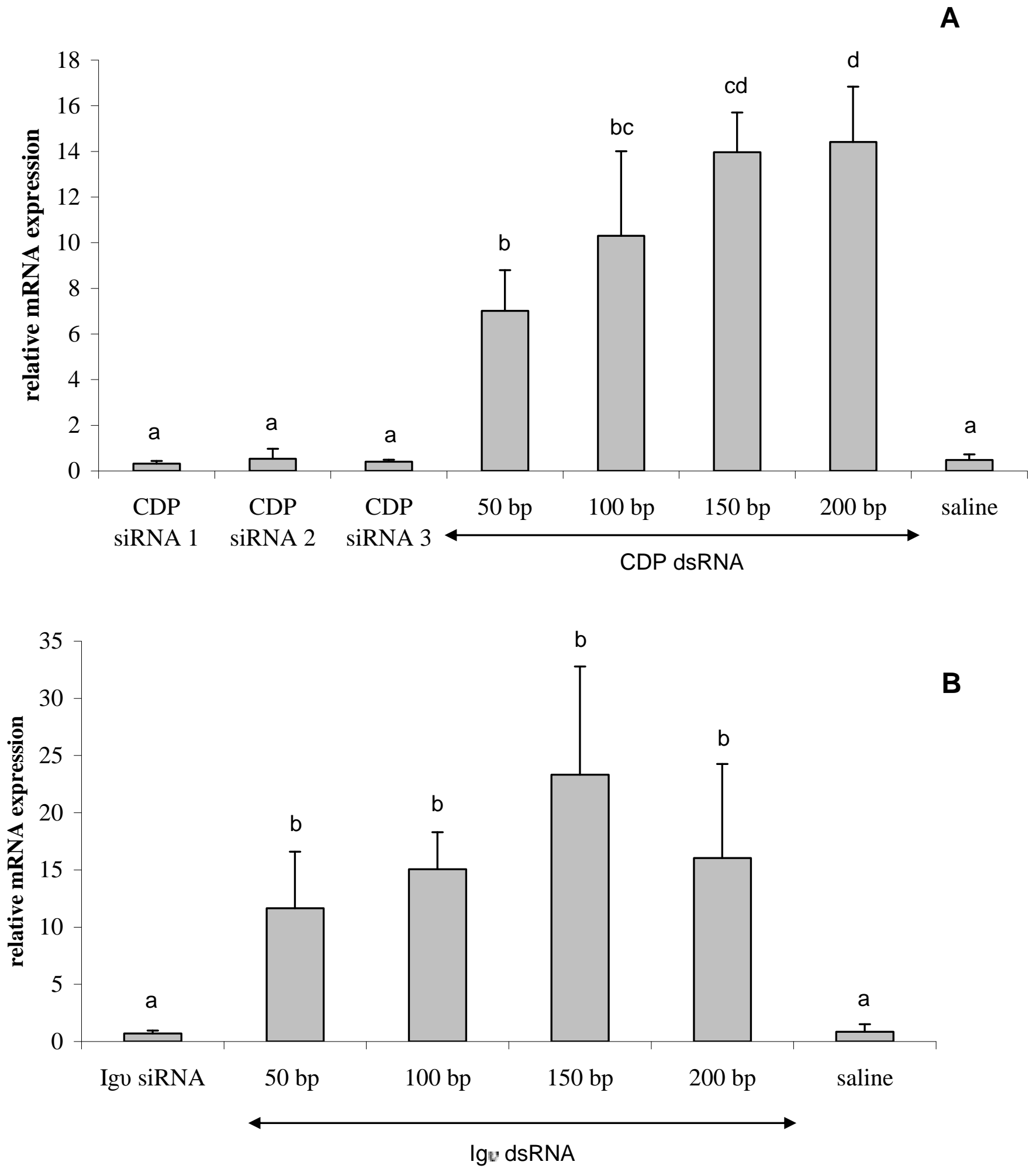
Figure 5. Lv-Sid-1 transcript abundance in shrimp gills $48 \mathrm{hrs}$ following treatment with either specific or non-specific siRNAs or dsRNA of varying lengths (ranging from 50 to $200 \mathrm{bp}$ ). Shrimp (1 to $1.5 \mathrm{~g}, n=10$ ) were injected with saline or $5 \mu \mathrm{g}$ of specific dsRNA or siRNAs targeting: CDP (CUB domain protein, AY907539), a shrimp endogenous gene (A), or the immunoglobulin $\mathrm{U}$ (Igu) gene from the duck, Anas platyrhynchos (AJ312200) (B). Five animals were randomly sampled in each group and LV-Sid-1 expression was determined in gill tissues of each individual shrimp by quantitative real-time qPCR. Expression values are presented as relative abundance in relation to S3A ribosomal gene. Bars represent \pm standard error of the mean. Different lower-case letters indicate significant difference between treatments.

Figure 6

A
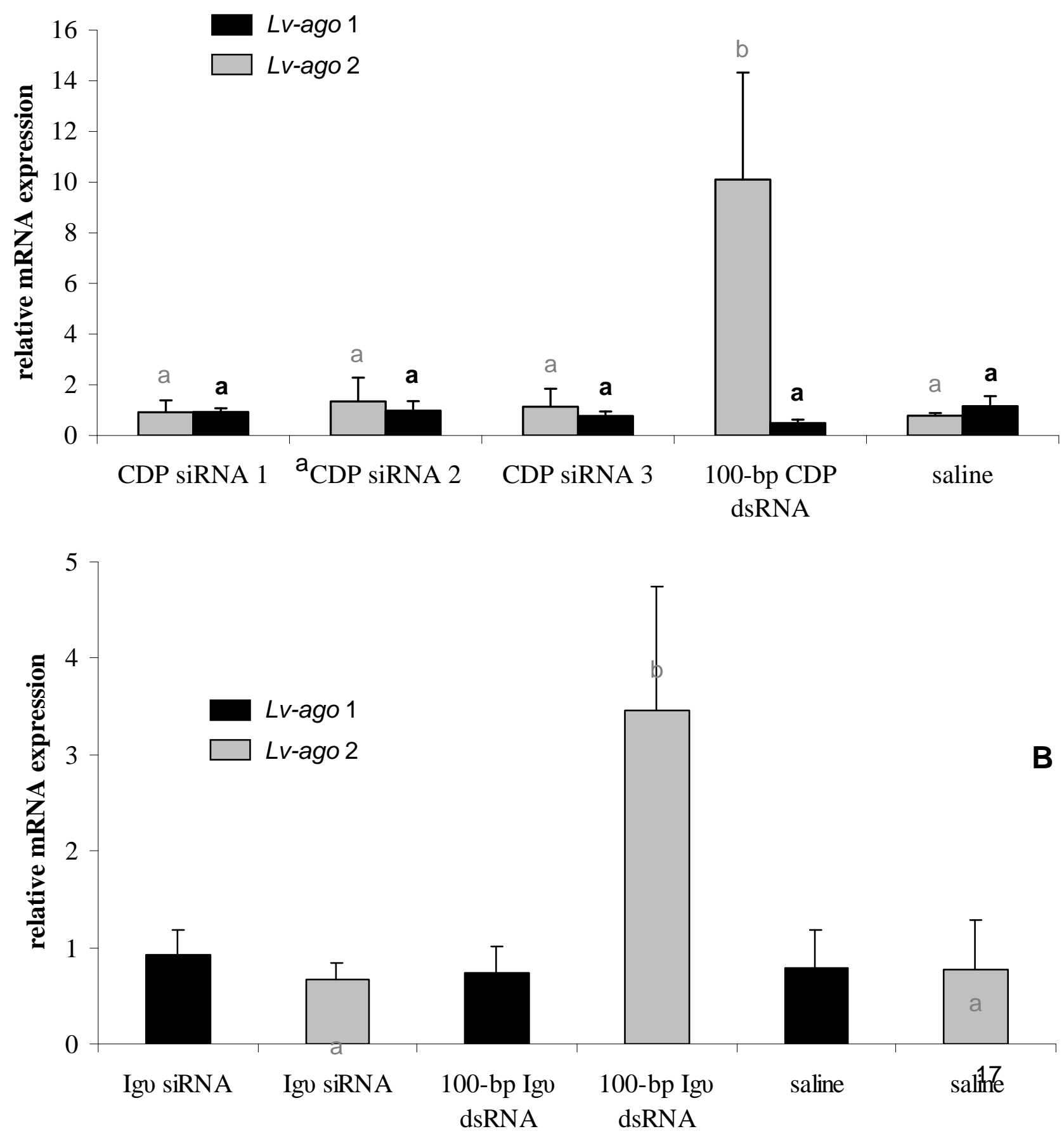
Figure 6. Lv-Ago 1 and Lv-Ago 2 transcript abundance in shrimp gills $48 \mathrm{hrs}$ following treatment with either specific or non-specific siRNAs or dsRNA of varying lengths (ranging from 50 to $200 \mathrm{bp}$ ). Shrimp (1 to $1.5 \mathrm{~g}, n=10$ ) were injected with saline or $5 \mu \mathrm{g}$ of specific dsRNA or siRNAs targeting $\operatorname{CDP}(\mathbf{A})$ or the duck immunoglobulin $U$ (Igu) gene (B). Five animals were randomly sampled in each group. Lv-Ago 1 and Lv-Ago 2 expression values determined by quantitative real-time qPCR are presented as relative abundance in relation to S3A ribosomal gene. Bars represent \pm standard error of the mean. Different lower-case letters indicate significant difference between treatments.

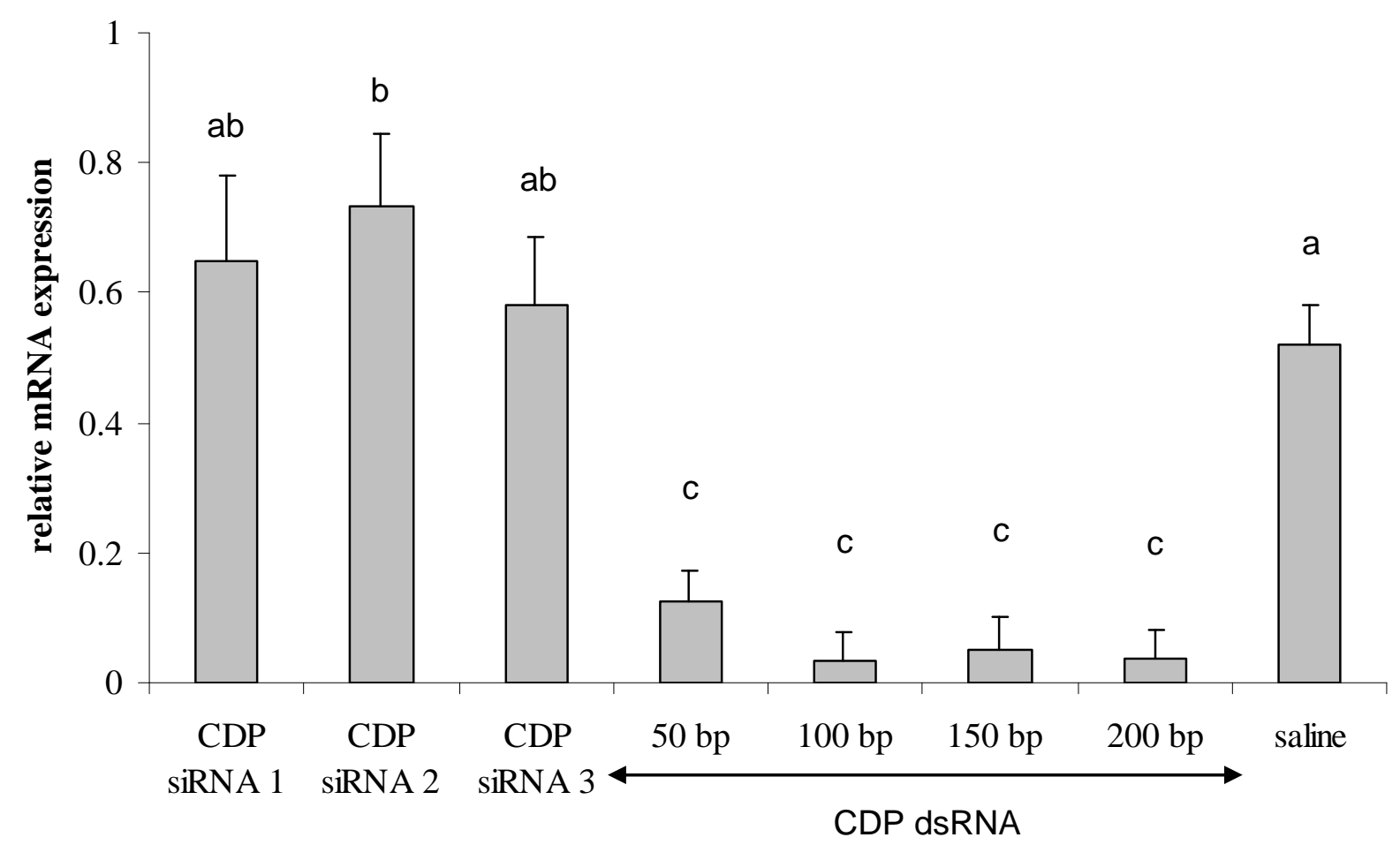

Figure 7. CDP transcript abundance in shrimp gills following treatment with sequencespecific siRNAs or dsRNA of varying lengths (ranging from 50 to $200 \mathrm{bp}$ ). Shrimp (1 to $1.5 \mathrm{~g}, n=10$ ) were injected on day 0 with saline or $5 \mu \mathrm{g}$ of siRNAs or dsRNA targeting CDP. At $48 \mathrm{~h}$ after this initial injection, 5 animals were randomly sampled in each group. CDP expression values determined by quantitative real-time qPCR are presented as relative abundance in relation to S3A ribosomal gene. Bars represent \pm standard error of the mean. Different lower-case letters indicate significant difference between treatments. 


\section{Figure 8}

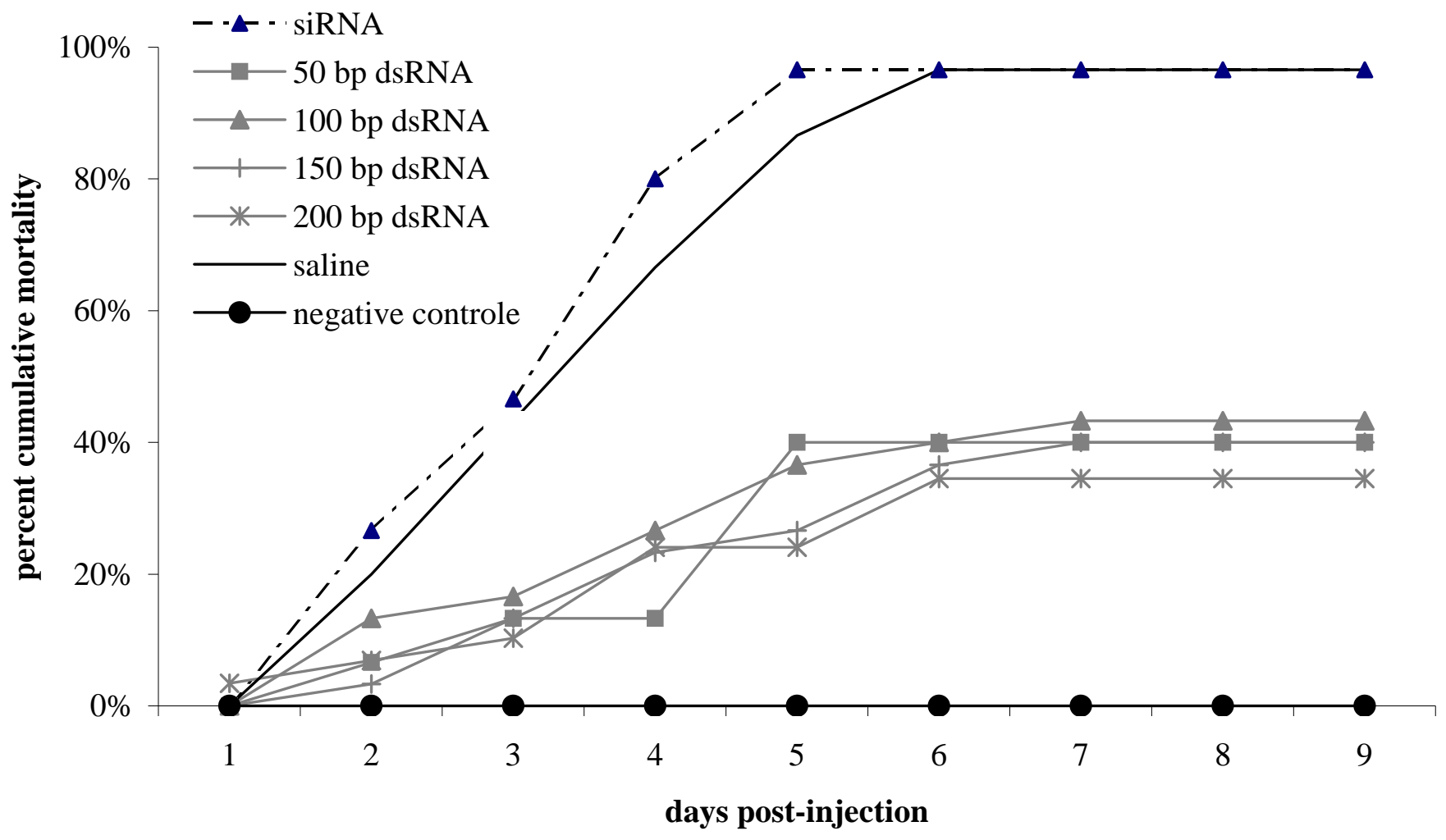

Figure 8. Shrimp mortality following treatment with non-specific siRNAs or dsRNA of varying lengths and experimental infection with WSSV. Shrimp $(n=30)$ were injected intramuscularly with either saline (positive [-] and negative [•] controls) or non-specific RNA duplexes (siRNAs or dsRNA ranging from 50 to $200 \mathrm{bp}$ ). At $48 \mathrm{~h}$ after this initial injection, animals were infected with WSSV. Differences in mortality levels between treatments were analyzed by Kaplan-Meier log-rank $\mathrm{X} 2$ tests. 


\section{Tables}

Table 1. List of primers used in this study. ${ }^{a}$ forward and reverse primers used to perform PCR and RACE-PCR to clone $L v$-ago $1, L v$-ago 2 and $L v$-sid 1 full-length cDNAs. ${ }^{b}$ forward and reverse primers used for measuring the expression of S3A (housekeeping gene, F023924) and $L v$-ago $1, L v$-ago 2 and $L v$-sid 1 by SYBR ${ }^{\circledR}$ Green real-time RT-PCR. ${ }^{c}$ forward and reverse primers used to amplify different size fragments (50, 100, 150 and 200 bp) from the full-length CDP (CUB domain protein) cDNA (AY907539) or from a 309bp portion of the immunoglobulin $U$ (Igu) cDNA from the duck, Anas platyrhynchos (AJ312200). 
Table 1

\begin{tabular}{|c|c|c|c|}
\hline $\begin{array}{c}\text { PCR and } \\
\text { RACE-PCR } \\
\text { primers }^{\mathrm{a}}\end{array}$ & Sequence $\left(5^{\prime} \rightarrow 3^{\prime}\right)$ & Target gene & $\begin{array}{c}\text { Primer } \\
\text { information }\end{array}$ \\
\hline G-3524 & CCA TGT TCC GTT ACC TGA AG & & gene cloning \\
\hline G-3525 & TCC CAC AGT ACG TGG TAG TG & & gene cloning \\
\hline G-3597 & TGT CTG GGT CGC GAG CCG TCA CTG GCA CT & Lv-ago 1 & RACE \\
\hline G-3595 & AGT GCC AGT GAC GGC TCG CGA CCC AGA CA & & RACE \\
\hline G-3816 & CCG TAG TTC ATA GAC TGC CAA TCG CTT CCA CCA & Lv-sid 1 & RACE \\
\hline G-3780 & GGC ATT TCC ATC CAT GAT CT & Lv-ago 2 & RACE \\
\hline G-3608 & CAC AGG AAG TCC CAT AGA ACG CCA & & confirming sequence \\
\hline G-3609 & CTT GAG GCA GAC TAG GTA AGG AGA GA & LV-ago 1 & confirming sequence \\
\hline G-3822 & ATG CCT TGG ATA TCA GAA GTC CTT C & & confirming sequence \\
\hline G-3823 & GAG ATA TCT GCC GCA GAA CCT GCT & LV-ago 2 & confirming sequence \\
\hline G-3853 & ATG ATG GCT CCA AAT CAC AGA GGT & Lv-sid 1 & confirming sequence \\
\hline G-3854 & AAA CAC ATG AAT TTT ATC GGA GCG & LV-sid 1 & confirming sequence \\
\hline
\end{tabular}

qRT-PCR primers ${ }^{b}$

\begin{tabular}{llcc}
\hline G-3832 & GCA GAG ATG CCC CTT CAA CTT & CDP & forward \\
G-3833 & AGG TAG CCC ACG GAA GCA A & Lv-ago 1 & reverse \\
\hline G-3644 & TGC GTC ATT TGC CAT CCA T & Lv-ago 2 & forward \\
G-3645 & GCC ATC TGG AGC GGA GAA G & Lv-sid 1 & reverse \\
\hline G-3851 & GAT GGC ATG AAG TCT GCA GTT G & S3A & reverse \\
\hline G-3852 & TGC GCA CGA CCA TCA CTA AG & forward \\
G-3846 & GAA GCG ATT GGC AGT CTA TGA AC & TGG AAG CCT ATC TCT GCA ACT TG & \\
G-3430 & GGC TTG CTA TGG TGT GCT CC & &
\end{tabular}

\section{PCR primers for preparation of different size dsRNA ${ }^{c}$}

amplicon length

(bp)

\begin{tabular}{llr}
\hline G-2544 & GGA TCA AAC TCA CCT GGC TGA & 50 bp with G-2544 \\
G-3836 & GCA GTC GGT GCA CCT CTC CA & 100 bp with G-2544 \\
G-3837 & ATC AGT TCC TTG GTT GTG TTG & 150 bp with G-2544 \\
G-3838 & ATG ATG TCA TAG TGG GAG G & CDP \\
G-3839 & ATA GTT TCT AGC ACT GTT GC & 50 bp with G-3840 \\
\hline G-3840 & CTG GCA GGG CGG CGT GTC CT & 100 bp with G-3840 \\
G-3841 & GCA ACC CTT CGT GGA CCA CCA & 150 bp with G-3840 \\
G-3842 & GAT GTC CAG CTC GGG GGT CT & Igv \\
G-3843 & CAG AGC CCG TCC AGT TCT TG & 200 bp with G-3840 \\
G-3844 & TGT AGC AGA CGC TGA GGA GG
\end{tabular}

